\title{
O papel do texto na aula de língua sob uma perspectiva interacionista
}

\author{
The function of the text in the language class \\ under an interactionist prospect
}

\author{
Le rôle du texte dans la classe de langue dans \\ une perspective interactionniste
}

Cleide Inês WITTKE

\begin{abstract}
RESUMO
A realidade do ensino de língua materna mostra que essa prática escolar não tem atingido os resultados almejados: que o aluno se expresse com segurança, clareza e naturalidade, tanto na modalidade falada quanto na escrita. Tal constatação reflete a necessidade urgente de redimensionar o objeto de estudo, bem como sua metodologia. Tendo como base teófíca as orientações dos Parâmetros Curriculares Nacionais (PCNs, 1998, 1999) e de vários estudos direcionados nessa perspectiva, tais como os de Geraldi (1991, 2006), Possenti (2002), Kleiman (1996, 2006), Neves (2003), Antunes (2003, 2007, 2009), citando apenas alguns, o presente artigo visa a problematizar a questão, não apontando fórmulas prontas, mas possibilidades de solução a serem efetuadas nas aulas de português. Definindo a língua e seu ensino como uma prática frequente de interảção verbal, vemos o texto (mais especificamente os diferentes gêneros textuais, que circulam em diversas instâncias sociais) como objeto de estudo e propomos-diferentes estratégias de leitura, análise linguístíca e produção textual como método para trabalhar a língua. Defendemos que o ensino e a aprendizagem de língua precisam funcionar como um constante trabalho de desconstruir e construir textos, enfim, como um exercício permanente de comunicação. E o ensino de gramática deve ser contextualizado, ou seja, mais do que identificar e classificar, o aluno precisa perceber o efeito de sentido que cada elemento linguístico produz, no contexto em que atua.
\end{abstract}

Palavras-chave: ensino, língua materna, interação verbal, texto, sentido. 


\begin{abstract}
The reality of teaching of language at school shows its effect isn't good because the student don't express himself with security, clarity and naturalness, as much as speaking or writing. This evidence reflects the necessity to reform the study's object and its methodology. Guided by theory of PCNs $(1998,1999)$ and another studies directed in this perspective, as Geraldi (1991, 2006), Possenti (2002), Kleiman (1996, 2006), Neves (2003), Antunes (2003, 2007, 2009), mentioning only some of them, this article to sight question this issue, without to point one formula, but it shows possibilities of solution that can use in portuguese's class. Defining language and its teaching as a frequent practice of verbal interaction, we see the text (different kinds of textual genres) as the study's object and we suggest some strategies of reading, analyses linguistic and writing like methodology to work language at school. We defend that teaching and teaching language need work as a constant exercise to construction and unmake the text, like a work of communication. The grammar's teaching must be in some context, more than identify and classify. The student needs to note the effect of sense that every element linguistic produces, in the context where work.
\end{abstract}

Index terms: teaching, language, verbal interaction, text, sense

\title{
RÉSUMÉ
}

La réalité de l'enseignement de la langue maternelle montre que cette pratique écolière n'a pas donné les résultats voulus: que l'élèvé se exprime avec sécurité, clarté et spontanéité, tant dans la modalité parlée autant que dans l'écrite. Cette remarque réfléte l'urgence de la nécessité de redimensioner l'objet de l'étude et sa méthodologie. Sur la base theorique de PCNs (Parâmetros Curriculares Nacionais - 1998, 1999) et de plusieurs études portant sur cette perspective, comme les travails de Geraldi (1991, 2006), Possenti (2002), Kleimann (1996, 2006), Neves (2003), Antunes (2003, 2007, 2009), pour mentionner seulement quelques travaux, cet article cherche à discuter la quéstion, sans pointer les formules prêtes, mais des possibiliés de solutions dans les classes de portugais. Avec la définition de la langue et son enseignement comme une pratique fréquente de l'interaction verbale, nous voyons le texte (les different genres textuels, existent en plusieurs situations sociaux) comme objet d'étude et nous proposons différentes stratégies de lecture, d'analyse linguistique et de production textuelle comme une méthode pour travailler la langue. Nous défendons que l'enseignement et l'apprentissage de la langue ont besoin de fonctionner comme un constant travail de déconstruire et construire des textes, $c^{\prime}$ est à dire comme un processus continu de comunication. Et 
l'enseignement de grammaire doit être contextualisé, c'est à dire, plus qu'identifier e classer, l'élève doit s'apercevoir de l'effet du sens que chaque élément linguistique produit dans le contexte où il opère.

Mots-clés: enseignement, langue maternelle, interaction verbale, texte, sens.

\section{Contextualizando o ensino de língua na escola}

O resultado obtido com o ensino de língua não tem sido visto como satisfatório pela grande maioria dos agentes envolvidos nessa prática pedagógica. Escola, professores, alunos, pais, enfim, a comunidade sente e se ressente do fracasso no efeito produzido na aula de português, em particular, e no ensino como um todo, de modo geral. Infelizmente, esse resultado não se trata de novidade, pois há algumas décadas vários estudos e experimentos dessa natureza vêm sendo realizados no meio acadêmico, todavia, no que tange à prática desse ensino na sala de aula, muito pouco tem mudado, prevalecendo a abordagem da gramática tradicional em detrimento do texto e do sentido que produz. Em vista disso, acreditamos ser pertinente continuar a abordar essa questão, buscando eneontrar alternativas de solução não só para o futuro professor, mas também ao

profissional em serviço. Iniciamos nossa reflexão questionando: onde estaria o problemâ? O que precisa ser repensado? O que deve mudar? Como proceder para que a aula de língua se torne um momento de interação em que alguém diz algo a outro alguém, de modo produtivo e autêntico? Como devemos proceder para que essa prática escolar faça sentido e diferença na vida diária de nosso aluno?

Com certeza, essas indagações, que hoje angustiam os professores de língua materna, poderiam suscitar inúmeras reflexões, apontando variadas respostas, nos diversos campos da ciência da linguagem. Um exemplo desta problematização pode ser observado nos PCNs que, de modo inovador e desafiador, reorganizam não só o objeto de ensino, mas também a 
metodologia a ser desenvolvida na aula de língua. É importante ressaltar que, embora essas orientações oficiais já tenham sido publicadas há uma década, elas ainda não fazem parte da realidade escolar, pois o material chegou à escola, mas não recebeu espaço para ser analisado e, se aprovado, posto em prática, ou melhor, adaptado à realidade de cada escola.

Considerando que a proposta nacional é pertinente ao ensino de língua almejado pela maioria dos educadores, entendemos ser nosso compromisso, enquanto professores universitários e formadores de profissionais da área, o de divulgar e auxiliar no processo de transposição didática desse material, o que pretendemos realizar também com esta reflexão. Entendemos que antes de pensar em elaborar novos Parâmetros (o que não impede que sejam ajustados ao contextual atual), é pertinente que se crie espaço e oportunidade para que a proposta vigente seja praticada na aula de português. Vale lembrar aqui a versão adaptada e atưl dos Parâmetros, que a Secretaria de Educação do Estado do Rio Grande do Sul vem estudando e realizando com os professores da rede estadual.

Em sua abordagem da e sobre a linguagem, os PCNs (1998, 1999) selecionam o texto como principal foco de estudo e concebem a línguảnão como conjunto de regras a serem descritas e classificadas (prescritas), mas como um processo de interação verbal, um trabalho, uma ação social, um saber a ser construído.

Sob esse enfoque, cientes do constante fracasso do ensino de língua na escola, e ainda da necessidade de redimensionar nosso objeto de estudo, direcionamos nossa trajetória reflexiva sob duas abordagens fundamentais: “o quê ensinar?" e "como ensinar?" que, sistematicamente, convergem a uma terceira questão: “para que ensinar?”. Defendemos que se o professor de língua resolver essas três perspectivas de modo centrado e com uma abordagem voltada ao desenvolvimento da competência comunicativa de seu aluno (tanto oral como escrita), poderá criar condições que oportunizem 
um estudo interessante e produtivo na sala de aula, um trabalho que realmente aperfeiçoe a capacidade comunicativa do educando.

\subsection{Primeira questão: o quê ensinar?}

Acreditamos que toda pessoa produz textos na medida em que se comunica por meio da palavra, sendo assim, definimos a aula de português como sendo uma prática diária de interação verbal, um espaço em que há constante comunicação, tanto oral quanto por escrito, implicando existir um locutor interessado em dizer algo a seu interlocutor. Nesse contexto, respondemos a primeira pergunta elegendo o texto como elemento essencial de estudo. Visando, então, a desenvolver a capacidade de comunicação de nosso aluno, sugerimos que o professor traga diferentes tipos de textos à sala de aula, criando oportunidades para que o aluno entre em contato e estude variados gêneros textuais, os quais circulam diariamente em nosso meio nas mais diversas situações sociais. Talvez, o mais sensato seja, conforme orientam Pereira et al. (2006. P. 29), "partir dos gêneros textuais mais familiares, para depois explorar outros, possibilitando aos alunes umá inserção cada vez maior na sociedade".

Ao assumir o texto como objeto de estudo, além de propor estratégias variadas de leitura e de produção textual, desconstruindo e construindo, é fundamental que o professor desenvolva diferentes atividades, evidenciando os processos de funcionamento linguístico, que são característicos dos diversos modos de organização do discurso. Isso implica analisar as estratégias que asseguram a coesão e a coerência, dominar o uso do vocabulário de modo criativo e dinâmico, estabelecer relação entre a classe e a função dos vocábulos na unidade maior que é o enunciado, exercitar o uso de frases que envolvem os processos de coordenação e subordinação, citando apenas algumas das atividades dessa natureza. 


\subsection{Segunda questão: como ensinar?}

Definido o que estudar, passamos a pensar nos possíveis modos de trabalhar nosso objeto de ensino (o texto) nas aulas de português. Tendo como base a abordagem teórica de Geraldi (1991, 2006), Ilari (1992), Possenti (2002), Travaglia (2002, 2004), Marcuschi (2002), Antunes (2007, 2009), direcionamos nossa prática diária a variadas estratégias de leitura, escuta e produção de texto (orais e escritos), as quais possibilitam o desenvolvimento da competência comunicativa, tanto falando quanto escrevendo.

Nesse momento de nossa reflexão, o leitor deve estar se perguntăndo e onde fica a gramática, principalmente a modalidade padrão, tão enraiźada em nosso ensino tradicional? Elimina-se completamente essa abordagem? Certamente que não, pois, continuamos a ensinar gramática na sala de aula (inclusive a variedade padrão, fundamental principalmente à competêncía da produção escrita), porém, com um enfoque diferente: visando ao domínio do funcionamento da língua em uso, e não à prática mecânica dá metalinguagem, com o mero objetivo de descrever e classificar, o que já está mais do que provado (e mostrado por vários autores ${ }^{1}$ ) que não faz sentido à vida prática do aluno, não havendo, portanto, necéssidade de ser trabalhado em aula. Defendemos, juntamente com Pereira et al. (2006, p. 27), que a metodologia a ser trabalhada na aula de português deve permitir que "o estudo da língua não se circunscreva a uma abordagem puramente gramatical, mas possibilite a ampliação da competência comunicativa dos alunos". Para tanto, acreditamos, assim como sugerem os PCNs (1998, 1999), tanto do Ensino Fundamental quanto do Médio, ser o texto elemento indicado a essa prática escolar.

\footnotetext{
${ }^{1}$ Entre vários desses autores, podemos citar Geraldi (1991), Ilari (1992), Bagno (1999), Possenti (2002), Neves (2003ab), Travaglia (2003), Antunes (2007).
} 


\subsection{Terceira questão: para que ensinar a ler e escrever textos?}

Como já foi dito anteriormente, a resolução das duas primeiras indagações desencadeia no terceiro aspecto. Depois de selecionar o texto como objeto de ensino, mais especificamente o gênero textual, com seu caráter funcional (discursivo, histórico e social), identificamos a prática de diversificadas estratégias de leitura e de produção textual como procedimentos metodológicos pertinentes a atingir o objetivo de nosso ensino de língua materna: promover o desenvolvimento do potencial comunicativo do aluno. Nossa reflexão sobre a prática didática e pedagógica visa a criar situações reais em que o aluno possa conhecer, desenvolver e aperfeiçoar sua capacidade de interagir, tanto através da fala quanto da escrita, no meio em que vive.

Como professores de língua, buscamos criar situações interativas em que o aluno possa exercer sua cidadania, desempenhar papel de sujeito de sua história, posicionando-se diante da realidade que o cerca. É importanté também que o conhecimento do funcionamento da língua, esse bem cultural tão precioso, sirva de subsídio para que desenvolva autonomia social, política e histórica. Acreditamos que se o aluno desvendar @s mistérios do funcionamento de diversos gêneros textuais que circulam socialmente, prática a ser desenvolvida na aula de português, familiarizando-se com eles, sentirá segurança tanto na hora de interpretá-los quanto de produzi-los. Assim, a prática de interação verbal será um recurso emancipatório e não de alienação, discriminação e exclusão, como vem ocorrendo ao longo da nossa atividade escolar. Sob essa ótica, somos solidários a Kleiman e Moraes (1999, p. 123) quando as autoras defendem que "a leitura crítica tem um potencial emancipador contra a fragmentação e a alienação, e o leitor crítico é, por definição, nunca mero decifrador". Isso implica que o texto seja elemento constante em nossa prática escolar. 


\section{A importância do texto na sala de aula}

Levando em conta que a palavra consiste em unidade de significado e o texto em unidade de sentido e de interação, defendemos, assim como os Parâmetros, que o texto deva ser elemento principal no ensino de língua (tanto no Fundamental como no Médio), tendo sempre o cuidado de ajustálo ao nível de conhecimento da série em questão. A partir dessa linha de pensamento, sugerimos que o professor selecione variados tipos de textos (em uma perspectiva pragmática e discursiva, diferentes gêneros textuais), em conformidade com as intenções e finalidades dos atos comunicativos, nos diferentes níveis de aprendizagem.

Grosso modo, ao selecionar o(s) texto(s) a ser(em) trabalhado(s) em aula, o professor precisa ter em mente a competência de leitura e de produção textual que pretende desenvolver com aquela atividade para poder avaliar se o material escolhido é adequado ao objetivo almejado. Cómo vemos, a escolha do(s) texto(s) é o primeiro passo ao sucesso de nossa prática de leitura e de produção textual, na sala de aula. Uma escolhá equivocada (inadequada) do texto pode resultar em uma prática tão improdutiva ao desenvolvimento da capacidade comunicativa quanto uma aula que aborde exclusivamente o exercício mecânico de metalinguagem. Conforme orientam Kaufman e Rodríguez (1995, p. 45), selecionar material de leitura aos alunos consiste em um ato avaliativo, ou seja, nas próprias palavras das autoras,

selecionar implica avaliar e, portanto, acatar o caráter de objeto passível de avaliação de todos os materiais de leitura: os objetos a selecionar passam a estar sujeitos a juízos racionais em função de diversos critérios a determinar. (...) Além disso, coloca-se em jogo a representação que tem cada docente não só do desenvolvimento cognitivo e sócio-afetivo dos sujeitos a quem vão dirigidos os materiais, mas também dos interesses de leitura de tais destinatários. Assim, também intervém como variável significativa o valor que o docente atribui aos materiais enquanto recursos didáticos. 
Enfim, o professor, além de ser criterioso na escolha dos textos (principalmente em função das temáticas abordadas e do nível de conhecimento do aluno), precisa ter o constante cuidado para que, ao serem extraídos de sua circulação social (de jornais, revistas, romances, TV, panfletos), não percam sua vivacidade, tornando-se mais um material escolar, presente em tantos livros didáticos disponíveis para o ensino de português. Nesse sentido, Chiappini (1997) orienta que a seleção de bons textos não garante um bom trabalho com a leitura. Como vemos, parece não haver mais dúvida de que o texto seja elemento fundamental ao ensino de língua na escola, portanto, é extremamente importante que ele seja bem entendido e definido. Tendo como base os PCNs, entendemos o texto cỏmo uma sequência verbal, completa e una, constituída por relaçõos estabelecidas via elementos de coesão e coerência. Em síntese, é mais do que um aglomerado de frases ou enunciados, consiste em "uma unidade significativa global" (PCNs, 1998, p. 21).

A partir dessa concepção, quando falamos em texto, estamos pensando em uma materialidade linguística de variada extensão que constitui um todo organizado de sentido, isto é, seja coerente e adequado à comunicação (tanto oral quanto escrita) a qual se propõe, em determinada situação social. Enfim, exerça adequadamente sua funcionalidade comunicativa. Para Marcuschi (2002, p. 24), se trata de "uma identidade concreta realizada materialmente e corporificada em algum gênero textual". Vemos, então, que o texto, ao circular socialmente, sob uma enorme gama de gêneros textuais, pode ser desde um enunciado como "Fogo!", uma poesia, uma crônica, uma bula de remédio, uma receita culinária, um e-mail, uma reportagem, uma charge, uma piada, uma notícia, um bilhete, um manual de instrução, um cardápio até um romance de várias unidades.

\subsection{Os gêneros textuais e sua funcionalidade}


Os gêneros textuais consistem nos diferentes formatos (materialidades linguísticas) que os textos assumem para desempenhar as mais diversas funções sociais, ressaltando suas propriedades sociocomunicativas de funcionalidade e de intencionalidade. Eles consistem em artefatos culturais historicamente construídos pelo homem e apresentam diferentes caracterizações, com vocabulários específicos e empregos sintáticos apropriados, em conformidade com a função social que exercem. Nessas condições, compete ao professor de língua criar oportunidades para que o aluno estude os mais diversos gêneros textuais, sua composição, estilo e funcionalidade, para que se tornem capazes não só de reconhecê-los e compreendê-los, mas também de construí-los de modo adequado, em seus usos variados, em diversos eventos sociais. Fazemos nosso o dizer de Geraldi (2006), quando especifica que o exercício dessas habilidades proporcionará o desenvolvimento da competência comunicativa dơ aluno, capacitando-o a um bom desempenho na sua vida diária (falando e escrevendo), nas mais diversas situações de interação verbal.

Nessa esteira, Brait (2002) lembra que ao estudar os gêneroई textuais, precisamos levar em conta diferentes aspectos que dizem respeito a seu processo de produção, circulação e recepção. Suas condiçães de produção e de recepção remetem ao questionamento: quem produz a mensagem para quem? Trata-se da identidade social do produtor e do receptor. Já a circulação refere-se ao veículo em que circula a mensagem. Tudo isso remete à mensagem em si, ou seja, por que aquilo é dito daquela maneira e não de outro modo? Ainda no que se refere às condições de produção, é preciso enfatizar que todo texto é determinado de acordo com a interação comunicativa estabelecida ente o produtor e o receptor, o que pressupõe regras, valores e normas de conduta advindas dos papéis sociais que os sujeitos desempenham na sociedade. Então, nos perguntamos: como podemos diferenciar o tipo do gênero textual? Quais são as implicações 
teóricas e funcionais desses elementos que viabilizam a materialização da língua?

\subsection{O que diferencia o tipo do gênero textual?}

Considerando que o gênero textual é uma questão de uso e a tipologia textual de forma, quando nos referimos à segunda modalidade, logo nos vem à mente as três estruturas características que organizam a sequenciação linguística e formal de dado texto, segundo as intenções manifestadas por seu produtor: narração (cuja intenção maior é contar uma história), descrição (cujo objetivo é apresentar, classificar e/ou analisar um objeto, um conceito, uma cena, um local, etc.), e dissertação (em que prevalece a intenção de informar sobre determinado assunto, de modo mais ou menos argumentativo - opinativo). Em abordagens teóricas mais recentes ${ }^{2}$, o terceiro aspecto tem sido denominado de argumentação (outros autores dividem a dissertação em argumentação e exposição), e duas novàs categorias textuais foram acrescentadas às três anteriores: o diálogo ou conversação (em que prevalece a conversa - oral e escrita - entre deis ou mais interlocutores) e a injunção (em que o produtor explicita a intenção de levar seu interlocutor a praticar atos ou executar ações- ou ainda, busca passar instruęões).

Sob tais condições, na medida em que essas seis (para alguns teóricos quatro e para outros cinco) modalidades textuais circulam no nosso cotidiano, em diferentes situações sociais, exercendo função interativa, passam a desempenhar o papel de gêneros textuais (discursivos), ampliando seu círculo de atuação, chegando mesmo a constituir um número ilimitado de exemplos. Podemos citar uma variedade enorme de gêneros textuais que atuam em diversos eventos sociais, mas, como são em número infinito, é

\footnotetext{
2 Dentre tais trabalhos, nomeamos os de Dolz, Rosat e Schneuwly (1991); Schneuwly (1994); Kaufaman e Rodrígues (1995); Bronckart (1999); Marcuschi (2002), Schneuwly \& Dolz (2004).
} 
praticamente impossível elencar a todos. Com vistas então a enriquecer nossa reflexão, citamos mais alguns deles tais como: telefonema, carta pessoal, carta comercial, lista de compras, reportagens de revistas, de jornais, crônica jornalística ou policial, poesia, roteiro teatral, editorial, narração de jogo de futebol, propaganda, outdoor, panfleto, romance, novela (escrita e falada), receita médica, resenha, edital de concurso, histórias em quadrinho, livro didático, anedota, resumo, resenha, entre muitos outros existentes em nossa sociedade.

Diante desse quadro nos perguntamos, com toda essa riqueza de material verbal interativo existente e precisando ser trabalhado na escola, continua sendo pertinente que o professor de português dedique tanto tempo de sua aula efetuando exercícios de metalinguagem, com o velho objetivo de identificar, classificar e avaliar? Será que tais atividades levarão nosso aluno ao objetivo almejado por grande parte dos professores de língua materna (talvez, de todos eles): que o aluno se comunique melhor, tanto falando quanto escrevendo? Essa mudança de postura exige um redimensionamento na escolha do material e no modo de abordá-lo. Então, seguimos nossá reflexão sobre o ensino de língua, investigando os principais aspectos a serem abordados nos textos selecionados e trazidos à sala de aula.

\section{Unidades básicas do ensino de língua: estratégias de leitura, oralidade, análise linguística e produção textual}

Com o objetivo desenvolver a capacidade leitora do aluno, cabe ao professor disponibilizar diversas estratégias, em variados gêneros textuais, que oportunizem o hábito de realizar leituras críticas, pelas quais o aluno possa entrar no texto e se posicionar diante da temática abordada. Dentre as diferentes atividades possíveis, citamos a mais comum que é o roteiro de leitura, pelo meio do qual o aluno-leitor pode entender a lógica do texto, em suas partes e no seu todo, compreendendo não só o que o autor quis dizer, 
mas também o faça refletir sobre o que foi dito, e do jeito como foi dito, ajudando-o a ficar mais informado e preparando-o para enfrentar as experiências do seu dia a dia, tornando-se um leitor competente e autônomo.

Tomando então o texto como ponto de partida, o professor pode criar oportunidades para que o aluno desenvolva sua oralidade. Para tanto, depois de trabalhar questões importantes relacionadas à fala, às regras que sustentam um diálogo, as trocas de turno, o professor pode promover debates, júris simulados, criar programas de $\mathrm{TV}$, de telejornais, de rádio, dramatizações, enfim, diversas atividades que estimulam e exercitam a prática oral da língua.

Compreendido a temática do texto, estimulada a oralidade, chega, então, o momento de expressar-se por meio da escrita. Dependendo do tipo de texto e do tema trabalhado, o professor pode sugerir inúmeras atividades de produção, com variados fins e leitores. Antes de começar a escrever, o aluno precisa saber por que ele vai escrever aquela mensagem e quem seră seu possível leitor. Precisa estar ciente do gênero que produzirá e conhecer suas características típicas tais como vocabulário e expressão, estrutura, estilo, bem como onde circula, enfim, considerar os aspectos de produção, circulação e recepção de um texto. É importante, nessa perspectiva, que alguém leia o texto produzido (não sendo "sempre" e somente o professor) e que o aluno tenha a oportunidade de reescrevê-lo, superando as dificuldades (de léxico, estrutura frasal e textual, coesão e coerência, conectivos, pontuação, grafia, concordâncias, regências etc.) que prejudicaram a qualidade da sua expressão escrita. Vale lembrar que definimos o texto como uma

Manifestação verbal, constituída de elementos lingüísticos de diversas ordens, selecionados e dispostos de acordo com as virtualidades que cada língua põe à disposição dos falantes no curso de uma atividade verbal, de modo a facultar aos interactantes não apenas a produção de sentidos, como a de 
fundear a própria interação como prática sociocultural $(\mathrm{KOCH}$, 2003, p. 31).

Dando então sequência à caminhada metodológica que visa a abordar um texto, chegamos a outra atividade fundamental do ensino de língua, que é o estudo e o aperfeiçoamento dos aspectos linguísticos (gramaticais), tanto na modalidade oral quanto e, principalmente, na produção escrita. Nossa proposta metodológica prevê que essa abordagem pode ser efetuada de dois modos diferentes: à partir das dificuldades apresentadas pelo aluno, na sua produção escrita; ou com base no texto fonte, em estudo. Acreditamos que os dois processos sejam válidos e produtivos, o importante é que o professor trabalhe tanto em um comó̀ em outro método de maneira pontual.

Nossa sugestão é que o professor selecione um aspecto gramatical observado no texto e trabalhe somente este: pesquisando na graphática, definindo e observando seu uso, através de exercícios que viabilizem a sistematização desse conhecimento. No caso da análise por meio da produção do aluno, entendemos que o aspecto gramatical mais importante á ser trabalhado seja aquele que sofreu maior desvio na medida em que comparado com a modalidade padrão, constatado em boa parte dos textos produzidos. Tais dificuldades podem ser no nível de concordância, regência, ortografia, pontuação, entre outras dessa natureza. Selecionado o aspecto linguístico a ser estudado, pode-se proceder do mesmo modo como foi sugerido no estudo do texto fonte: pesquisa na gramática, definições e exercícios capazes de estimular o uso da língua padrão.

Inspirando-se na proposta sociointeracionista de ensino de língua sugerida pelos PCNs, e na perspectiva desenvolvida por Geraldi (2006), no seu livro "O texto na sala de aula", a presente abordagem teve o intuito de estudar a língua com base nas unidades que, a nosso ver, devem constituir o ensino de português na escola: prática de leitura, de oralidade, de produção textual e de análise linguística. Esboçado então nosso projeto (não como 
modelo, mas como sugestão, entre tantas outras possíveis) de como abordar um texto na aula de língua, sob diferentes perspectivas metodológicas, é chagado o momento de colocá-lo em prática.

\section{0 texto vivo na sala de aula: uma realidade possível}

Sem a pretensão de sermos exaustivos ou querer ditar modelos, mas com a intenção de orientar e indicar alguns caminhos possíveis ao professor que atua no Ensino Fundamental e Médio, na tarefa de abordar o texto, e seus efeitos linguístico-discursivos, construímos uma proposta para trabalhá-lo na aula de português. A título de exemplo, desenvolvemos uma atividade de leitura, análise linguística e produção textual, a partir de um pequeno texto extraído do Jornal Correio do Povo, publicado em 16-07-09. Vale lembrar aqui nosso ponto de vista de que

A linguagem se justifica pelos sentidos que expressa, pelas intenções que manifesta. Sentidos e intenções que decorrem dos valores culturais dos grupos onde vivemos e interagimos. Durante muito tempo, em muitas aulas de língua, perdemos de vista este componente semântico, este componente pragmático da linguagem e nos detivemos em análises de sua morfologia e de sua sintaxe, como se essas coisas tivessem vida por si mesmas (ANTUNES, 2009, p. 119).

Selecionamos esse texto jornalístico por entender que se trata de uma produção interessante, com temática atual e de fácil entendimento aos alunos. Além disso, por apresentar um título instigante e dar margem ao estudo interdisciplinar com outras áreas tais como: Geografia, Matemática, Língua Estrangeira (LE), História e Educação Física (EF). Por exemplo, a Geografia poderia entrar com o entendimento da localização espacial, mostrando no mapa a trajetória percorrida por Fabiano; enquanto a História explicaria questões sociais e culturais desses locais; a Matemática explicaria a questão do tempo marcado na corrida (1min46seg03) e da conversão do 
dinheiro; a LE faria a tradução e contextualização das palavras em outras línguas (Meeting e tour); e a $\mathrm{EF}$ esclareceria aspectos da modalidade esportiva abordada no texto, dentre outras perspectivas possíveis.

A princípio, elaboramos uma proposta de estudo voltada a um $5^{\circ}$ ou $6^{\circ}$ ano do Ensino Fundamental (I), mas nada impede que as atividades sejam ajustadas ao $7^{\circ}$ ou $8^{\circ}$ ano (EF-II), e até mesmo ao Ensino Médio. O importante é que os exercícios sejam adequados ao nível de conhecimento dos alunos, sendo que, na medida em que os anos vão avançando, mais espaço se abre ao estudo da metalinguagem, não na perspectiva normativa (identificar e classificar), mas funcional (entender o papel que desempenha no sentido produzido pelo texto como um todo uno).

\section{Texto:}

\section{Fabiano Peçanha é diamante em Lucerna, na Suíça}

Atletismo - O meio-fundista Fabiano Peçanha, do Pinheiros (SP), venceu a prova dos 800 metros rasos no Meeting Internacional de Lucerna, na Suíça, ontem. Ele marcou 1 min46seg03 e como prêmio recebeu um diamante no valor de $€ 1,7 \mathrm{mil}(\mathrm{R} \$ 4,6 \mathrm{mil})$. Hoje o atleta se transfere para Lisboa, em_Portugal, onde treina para a próxima-prova do seu tour pela Europa, no dia 24 deste mês, em Londres, Inglaterra. Fabiano se prepara para a disputa dos 800 metros do Mundial de Berlim, a partir de 20 de agosto.

\section{ATIVIDADE I}

Poderíamos iniciar nosso estudo, apresentando apenas o título e solicitando aos alunos o que eles entendem e o que esperam encontrar no texto que será lido. Passado esse primeiro momento de debate, eles leem o referido texto e resolvem, por escrito, as seguintes questões: 
1 Sobre o que fala o texto? Qual é sua mensagem?

2 Quem escreve a notícia e a quem se dirige?

2 Em que seção do jornal normalmente encontramos notícias dessa natureza?

3 No seu entender, o título está claro ou é preciso ler o artigo para compreendê-lo? Será que o redator fez isso de propósito?

4 Percebemos dois momentos temporais diferentes no texto. Quais são as duas palavras (os dois advérbios de tempo) que marcam esses dois momentos na vida de Fabiano Peçanha? (ontem e hoje)

5 Quais são os verbos que aparecem nos dois primeiros enunciados? A que tempo verbal eles remetem? Na prática, o que isso quer dizer? (venceu - marcou e recebeu) (passado - Pretérito Imperfeito do Indicativo)

6 Quais são os verbos que atuam nos $3^{\circ}$ e $4^{\circ}$ enunciados? Em que tempo verbal eles estão conjugados? Essas ações estão acontecendo ou irão acontecer? Por que o autor do texto empregou o presente e não o futuro? Isso é comum em notícias de jornal? (se transfere - treina e se prepara)

7 Todos os seis verbos que auxiliam na produção do sentido do texto são de ação, o que isso quer dizer? Vamos pesquisar nas gramáticas para entender melhor a função dessas palavras no texto.

8 Normalmente, o uso dos verbos de ação implica que alguém (sujeito) faz (ação) algo (objeto direto) para outro alguém (objeto indireto). No texto lido, quem pratica a ação de vencer, marcar e receber? Ou seja, quem é o sujeito dessas ações? Venceu, marcou e 
recebeu o quê? De quem? Enfim, quais são os complementos dessas ações?

9 Quais são os sujeitos dos verbos transferir-se, treinar e preparar-se? Todos precisam de um complemento na sua informação?

10 Qual é o papel semântico do complemento (objeto direto e indireto) nos verbos de ação? (pesquisar nas gramáticas)

Após corrigir e discutir as respostas dadas às questões, sanando as dúvidas, caso haja, continuamos nossa proposta de aula, com nôvos exercícios.

\section{ATIVIDADE II}

Seguindo nosso estudo do texto, dando ênfase à abordagem gramatical, que enfatiza o papel do verbo na construção do sentido, propomos mais duas questões:

\section{ENUNCIADO (A)}

"Juliana prepara o almoço para seu noivo, pois ele não gosta de comer em restaurantes. Hoje, éla está fazendo risoto, saladas e batata frita, já que é um dia especial: está fazendo um ano que se conheceram e começaram a namorar."

Proposta - O verbo empregado no texto jornalístico (se prepara) tem o mesmo sentido do verbo preparar desse enunciado? Compare os dois usos e explique o que ocorre em cada um deles.

\section{ENUNCIADO (B)}


"Sempre que possível, a gente transfere a sede da Instituição para o centro da cidade, pois o atendimento fica mais acessível e mais ágil. Porém, quando não dá, atendemos na periferia."

Proposta - O verbo transferir, empregado no texto, tem o mesmo sento desse usado no enunciado 2? O que ocorre? Explique as duas situações.

(Seria interessante sugerir, aqui, uma pesquisa nas gramáticas, abordando o caso específico dos verbos pronominais!) Além disso, poderíamos sugerir que o aluno empregasse os verbos estudados em outros contextos, diferentes dos já abordados no texto jornalístico e nos dois enunciados.

Vários outros aspectos linguísticos e discursivos poderiam ser estudados no texto selecionado, tais como questões de coesão e coerênncia, envolvendo os pronomes, os dêiticos e conhecimento de mundo, pơr exemplo. Como o leitor deve ter percebido, exploramos de modo mais enfático o estudo gramatical, tendo em vista que essa abordagem tem sido a mais problemática no momento de analisar os elementos linguísticos em uso, construindo sentido, abandonando, assim, as fortes raízes dă gramática normativa, que estuda as regras da língua como se elas tivessem existência própria, mesmo descontextualizadas.

\section{ATIVIDADE III}

Produção textual - Dentre as variadas possibilidades de produzir novos textos, sugerimos que o aluno assuma o papel de redator do Jornal Correio do Povo, use sua criatividade, e redija uma nova notícia esportiva, descrevendo o resultado obtido por Fabiano Peçanha, após a disputa dos 800 metros no Mundial de Berlim, projetado na notícia lida.

\section{AVALIAÇÃo}


No que tange à avaliação do conteúdo gramatical abordado, não temos a intenção de cobrar a devolução das regras em prova, simplesmente reproduzindo o conteúdo expresso na gramática, mas descontaremos pontos em trabalhos escritos futuros, caso o aluno deixe de empregar adequadamente o conteúdo gramatical pesquisado e estudado em aula (aqui, no caso, alguns aspectos do verbo e seu uso), pois entendemos que o conteúdo só foi assimilado se for empregado, em atividades futuras. Com certeza, nosso trabalho surtiria bem mais efeito caso tivéssemos todos os professores da escola engajados nessa avaliação (exigência), pois não é só na aula e nas atividades de português que o aluno precisa escrever respeitando as regras da gramática, mas em qualquer momento em que se expressa, principalmente por escrito, seja qual for a área de estudo.

\section{Concluindo}

O objetivo do presente estudo foi mostrar ao professor de língua (e ao futuro profissional) a importância de trabalhar o texto (diversos gêneros textuais) na aula de português, sob diferentes estratégias de leitura, análise linguística e produção textual. Em síntese, produzimos uma reflexão cơm o intuito de enfatizar que a aula interativa, com construção de conhecimentos signifieativos é uma realidade necessária e possível, portanto, o meio acadêmico precisa incentivar e orientar a realização dessa prática pedagógica. Levando em conta o atual contexto do ensino de língua materna, que monopoliza a prática de exercícios mecânicos de metalinguagem, ignorando ou usando o texto como mero pretexto para estudar regras gramaticais, buscamos apresentar argumentos e caminhos práticos que mostrem ao professor que o texto é realmente uma materialidade adequada para desenvolver a capacidade comunicativa de nosso aluno. Procuramos mostrar também que a proposta dos PCNs é viável e vem ao encontro de nossos objetivos de desenvolver a potencialidade 
interativa, portanto, vale a pena dedicar tempo analisando-a e então ajustá-la à nossa prática diária, na escola.

Sob uma perspectiva sociointeracionista, defendemos que a aula de português deve funcionar como um trabalho de interação verbal, portanto, tem a função social de promover a capacidade de ler, debater e entender os gêneros textuais que circulam em nosso meio, bem como de produzi-los em conformidade com as convenções sociais que determinam suas características e funcionalidade. Definimos a prática de ensino de língua como um exercício permanente de desconstrução e construção de textos, atividade que capacita o aluno a interagir com segurança e competência nas complexas situações que o cotidiano the proporciona. Defendemos que é de fundamental importância que o aluno leia e escreva com bastante frequência, pois essa prática o auxiliará no aperfeiçoamento de seu potencial comunicativo.

Afinal, somos seres sociais e estamos em constante interação com o outro que nos cerca. Nesse contexto, vemos a aula de português comó sinônimo de ler e escrever textos autênticos e típicos de nosso convíivio social, nos mais variados gêneros: literário, jornalístico, didático, midiático, científico, humorístico, dialogal, publicitário, cinematográfiço, entre muitos outros existentes e que ainda surgirão. Entendemos, nessa perspectiva, o papel do professor de língua materna como o do profissional que media o conhecimento do aluno (sua aprendizagem) com o vasto e rico material verbal que circula em nosso meio social. Encerramos o presente estudo com o dizer de Antunes (2007, pp.51-52), quando a autora defende que a "gramática, sozinha, é incapaz de preencher as necessidades interacionais de quem fala, escuta, lê ou escreve textos. Daí que, em um programa de ensino de línguas, deve constar mais que uma série de itens de gramática" (grifo da autora). E o texto surge como uma nova possibilidade de mediar o ensino e a aprendizagem de língua, no meio escolar. Segundo a 
mesma autora (2009, p. 174): "Logo, falando, ouvindo, lendo, escrevendo é que vamos incorporando e sedimentando os padrões da língua. Não há outro jeito!".

\section{REFERÊNCIAS BIBLIOGRÁFICAS}

ANTUNES, I.. Aula de português encontro \& interação. São Paulo: Parábola, 2003.

Muito além da gramática: por um ensino de língua sem pedras no caminho. São Paulo: Parábola, 2007.

Parábola, 2009.

Língua, texto e ensino: outra escola possível. São Paulo:

BAGNO, M.. Preconceito linguístico: o. que é, como se faz. São Paulo: Edições Loyola, 1999.

BRAIT, B. PCNs, gêneros e ensino de língua: faces discursivas da textualidade. In: ROJO, R (org.). A prática de linguagem na sala de aula. Praticando os PCNs. São Paulo: Mercado Aberto, 2002.

BRONCKART, J-P.. Atividade de linguagem, textos e discursos. São Paulo: PUC-SP, 1999.

CHIAPPINI, L. Aprender e ensinar com textos didáticos e paradidáticos. v. 2, São Paulo: Cortez, 1997.

DOLZ, J; ROSAT, M-C; SCHNEUWLY, B.. Élaboration et évaluation de deux séquences didactiques relatives de trois types de textes. Le français aujourd'hui, n. 93, p. 37-47, Paris, 1991.

GERALDI, J.W.. Portos de Passagem. São Paulo: Martins Fontes, 1991. (org.) O texto na sala de aula. São Paulo: Ática, 2006.

ILARI, R.. Lingüística aplicada ao ensino de português. Porto Alegre: Mercado Aberto, 1992.

KAUFMAN, A.M. \& RODRIGUES, M.H.. Escola, leitura e produção de textos. Porto Alegre: Artes Médicas, 1995. 
KLEIMAN, A.; MORAES, S. E.. Leitura e interdisciplinaridade: tecendo redes nos projetos da escola. Campinas: Mercado de Letras, 1999.

KLEIMAN, A.. Oficina de leitura: teoria e prática. São Paulo: Pontes, 1996.

Leitura e prática social no desenvolvimento de competências no ensino médio. In: BUNZEN, C. e MENDONÇA, M. (Orgs.). Português no ensino médio e formação do professor. São Paulo: Parábola, 2006.

KOCH, V. I.. O texto e a construção dos sentidos. São Paulo: Contexto, 2003.

MARCUSCHI, L. A.. Gêneros textuais: definição e funcionalidade. In: DIONÍSIO, A.P.; MACHADO, A. B.; BEZERRA, M. A... Gêneros textuais \& ensino. Rio de Janeiro: Lucerna, 2002.

MEC/SEF. Parâmetros Curriculares Nacionais (PCNs) $-3^{\circ}$ e $4^{\circ}$ ciclos do ensino fundamental: Língua Portuguesa. Ministério da Educação e de Desportos Secretaria de Educação Fundamental, Brasília, 1998.

Parâmetros Curriculares Nacionais do Ensino Médio Linguagens, códigos e suas tecnologias. Brasília: Ministério da Educação, 1999.

NEVES, M. H. M.. Gramática na escola. São Paulo: Contexto, 2003a.

Que gramática ensinar na escola?. São Paulo: Contexto, $2003 \mathrm{~b}$.

PEREIRA,--C.C.-et. al. Gêneros textuais e modos de organização do discurso: uma proposta para a sala de aula. In: PAULIUKONIS, M. A. L. e SANTOS, L.W. (Orgs.). Estratégias de Leitura - Texto e ensino. Rio de Janeiro: Lucerna, 2006.

POSSENTI, S.. Por que (não) ensinar gramática na escola. Campinas: Mercado de Letras, 2002.

SCHNEUWLY, B.. Qu'est-ce qu'apprendre/enseigner à lire et à écrire aujourd’hui?. Recherches, n. 20, p. 51-60, Lille, 1994.

SCHNEUWLY, B. \& DOLZ, J. et al. Gêneros orais e escritos na escola. São Paulo: Mercado de Letras, 2004. 
TRAVAGLIA, L.C. Tipos, gêneros e subtipos textuais e o ensino de língua portuguesa. In: BASTOS, N. (Org.). Língua portuguesa: uma visão em mosaico. São Paulo: EDUC, 2002.

Gramática e interação:uma proposta para o ensino de gramática. São Paulo: Cortez, 2003.

- Tipologia textual, ensino de gramática e o livro didático. In: HENRIQUES, C. \& SIMÔES, D. (Orgs.). Língua e cidadania: novas perspectivas para o ensino. Rio de Janeiro: Ed. Europa, 2004.

\section{Texto estudado}

Fabiano Peçanha é diamante em Lucerna, na Suíça. Jornal Correio do Povo, publicado em 16-07-09 (não aparece explícito o nome do autor).

\section{Autora:}

Cleide Inês Wittke

Universidade Federal de Pelotas

Contato: cleideinesw@yahoo.com.br

Texto recebido em março de 2011.

Texto aprovado para publicação em junho de 2011.

\section{Como citar este texto:}

WITTKE, C. I.. O papel do texto na aula de língua sob uma perspectiva interacionista Revista Acolhendo a Alfabetização nos Países de Língua Portuguesa, Brasil, São Paulo, volume 1, nº 11, pp. 103 - 126, Set.. 2011. Disponível em: <http://www.acoalfaplp.net>. 